\section{Blood on the chair}

In one of the most audacious examples yet seen of the tobacco industry buying the respectability which its core operations so utterly deny it, BAT Industries has found that even one of the world's most famous universities has a price. Few would have suspected that Cambridge, one of Britain's most ancient and revered seats of learning, would sell its soul for a comparatively paltry $£ 1.6$ million (US $\$ 2.4$ million). But in March, the university issued a press release which began: "As part of its commitment to education," which might have been expected to continue something like: "Cambridge University is pleased to announce. . . ". In fact, it continued: "BAT Industries is to endow a Professorship of International Relations at Cambridge in honour of Sir Patrick Sheehy, who retired as Chairman of BAT Industries at the end of December". The oleaginous text, which looked as if it had been drafted by BAT's public affairs department, went on to describe the "Sir Patrick Sheehy Professorship" and related scholarships carrying BAT's name, complete with unctuous quotes and information about Sir Patrick.

The head of the university's medical school interrupted a world lecture tour as soon as he heard the news, and returned to Cambridge for some plain talking with the vicechancellor and other members of staff. Letters of protest poured in from former students and others outraged that the university was to contaminate itself not only by taking BAT's money, but by lending its lustre to a man whose most obvious commitment to international relations had been the deliberate expansion of tobacco sales in developing countries, often by the most aggressive marketing strategies. As it was put by Sir Richard Doll, the renowned epidemiologist who was one of the first to firmly establish the link between smoking and serious diseases such as lung cancer, "Sir Patrick's contribution to society... has been to cause a great deal of disease."

Apparently overlooking the certainty implied in the press release (one wonders whether BAT pushed the university press office into issuing it, assuming there would be fierce opposition), the vice-chancellor backtracked to explain that the decision was not final, and that academic staff could in due course press the matter to a vote. The university duly acceded to a vote of senior academic staff in July, strongly recommending acceptance and got its way by 1128 votes to
583. In addition to angry accusations of "blood money" from those who voted against it, the outcome drew an announcement from the Cancer Research Campaign, one of the UK's largest cancer charities, that it would consider withholding future research funding from the University.

The man on whom Cambridge will bestow such a substantial honour seems unlikely to add to the university's academic prestige, if his grasp of science is anything to go by. In 1990, he told a British newspaper: "BAT's policy is very clear. Our view is that smoking has not been established to be the cause of disease". Nor are his special contributions to BAT likely to give students of moral philosophy any or special reason for celebration. His earnings in 1992, before he began to scale down his work for the group, 을 were just under a million pounds (US\$1.5 million), of which over a third was performance related. In that $\overline{\bar{D}}$ year, "Commercial activities" (of $\overrightarrow{0}$ which over $90 \%$ was tobacco) were up by more than a quarter over the previous year, and accounted for two-thirds of the group's profits. Thus much of the performance that earned Sir Patrick his extra pay related to increased tobacco sales. In his Chairman's statement to shareholders, he outlined the three key elements of strategy that had made the group's tobacco trading so successful: improving the share of existing markets; increasing exports; and "actively investing in new markets that are opening up."

Readers of this journal will be familiar with examples of all these elements of strategy. The last one may be of special interest to students at the Centre of International Studies, where the new Professorship will be based. They may want to consider the tactics used by the BAT in its overseas markets, especially those where it believes that public knowledge of the dangers of smoking may be less advanced than in its home country. Some good examples of these tactics were illustrated by the "hit squad" that went to Sri Lanka and South Africa in October 1993, and clearly showed the lengths to which BAT will go to mislead people about the nature of smoking (Tobacco Control 1994;3:76-7). In trying to make Sri Lankans and South Africans believe that smoking was not harmful, Sharon Boyse, head of BAT's Smoking Issues Department, said that smoking was “simply a 'risk marker' for diseases like lung cancer, in the same way that driving licences are risk markers for car accidents". Exactly the same "driving licence" trick was used earlier 
that year by a BAT delegation to Lithuania, no doubt one of the new markets the chairman had in mind, in connection with BAT's imminent investment in a new factory there.

Such false arguments are clearly part of company policy. These were not random incidents, nor were they a case of staff being caught unprepared by journalists. The team that went to Sri Lanka and South Africa was sent out specifically to generate press coverage for misleading, anti-health propaganda. In all three countries, senior BAT staff repeated the overall company policy, as outlined by their chairman, that smoking has not been established to be the cause of disease. Earlier this year, the same Ms Boyse, now apparently billed as a "tobacco consultant", but still citing her BAT pedigree, told Sunday Life newspaper in Barbados (10 March 1996) that the advice of doctors and medical authorities about smoking being the cause of disease was "simplistic". The tobacco industry did not dispute smokers' greater statistical risk of disease, she said, but "I study science so I like to take a deeper look at why that is". She went on to stress "We're not trying to sell anybody a line. We just think that sometimes the emotion of the debate gets in the way of science.... The only point the tobacco industry and many other independent scientists are trying to make is that at the moment we really don't know, smoking might cause disease or it might not."

Such public, targeted denials of the truth are nothing new. In 1982, the year Sir Patrick became chairman, BAT sent senior officials from the UK to conduct propaganda work in Hong Kong. They gained widespread publicity clearly aimed at trying to ward off tobacco control legislation in the colony (though ironically, this eventually led to Hong Kong taking the problem seriously for the first time). The previous year, BAT's Director of Research and Development had published "Ten Key Facts" on the "smoking and health controversy".

In addition, the Centre of International Studies may find that BAT has a rather biased understanding of the term "international relations". For transnational companies, and especially for tobacco companies, it is primarily about trade, and in particular, about getting their own way wherever they operate (in more than 90 countries, in BAT's case), with as few constraints as possible. With BAT's long-term future for tobacco sales lying mainly in developing countries and those of central and eastern Europe, it is not surprising that this special interest is reflected at the very top: the new chairman, Lord Cairns, has a long history in international relations; and in 1993, the former US Secretary of Agriculture and US trade representative, Clayton Yeutter, was added to the board of directors.

Perhaps some of the less worldly staff at Cambridge may also be asking themselves why a company devoted to making money from selling tobacco should have a "commitment to education", and one which, according to the press release, covers more than 450 universities around the world. Surely such a commitment would be an abuse of shareholders' money? Their more experienced colleagues may be able to explain how considerable influence can be gained from sponsoring a university, especially in less-developed countries, where such funding is desperately hard to find. And if any moral scruples crop up in these countries about taking tobacco money, they will be much easier to overcome by mentioning the Sir Patrick Sheehy professorship and the BAT scholarships at the University of Cambridge.

DAVID SIMPSON Nezus Editor

\section{Liggett comes clean}

Although it is far too early to assess the final outcome of Liggett's decision to settle the Castano class action lawsuit and lawsuits by a half dozen US states $^{*}$, it is already clear that it is the most important change in tobacco company policy since the dangers of smoking first became known.

In March, Liggett, a subsidiary of the Brooke Group and manufacturer of Chesterfield, Lark, Eve, and L\&M cigarettes, broke ranks with the rest of the US tobacco industry by offering to reach a multi-million dollar out-ofcourt settlement with tobacco control litigants. Liggett only has about $2 \%$ of the US market, but its decision rocked the tobacco industry and Wall Street alike. It will be the first time any US tobacco manufacturer has paid money to settle such a tobacco liability lawsuit. Liggett's move came as it faced a new type of lawsuit, the Castano class action suit, in which lawyers are seeking compensation on behalf of all present and former smokers not for health damage, but for the costs of their nicotine addiction, including a refund of money spent on cigarettes.

Liggett's proposed deal will settle both this case and also the separateand novel-litigation in which a half 